\title{
Primary teachers go beyond the Slovak civic education curriculum
}

\section{Zuzana Danišková, Ivan Lukšík}

\begin{abstract}
A number of studies have pointed to the low level of civic participation among young people. On the other hand, there is a section of the youth population that is politically involved in and supportive of extremist and anti-system political movements. Public discussions have suggested that this may be linked to inadequacies in citizenship education. However, as the Slovak case shows, the causes of this are deeper, have historic roots and are reflected in the fact that citizenship education has been pushed to the margins of the curriculum and is narrowly interpreted. Citizenship education is not just about the nature of the curriculum but also about broader extra-curricular activities and about the direct, or implicit, instruction provided by teachers. The empirical research presented here shows that primary school teachers go beyond the narrow framework of the national social studies syllabus and implicitly teach citizenship education in line with their own civic orientations.
\end{abstract}

Key words: citizenship education, primary education, social studies, Slovak social studies.

\section{Introduction}

As McCowan (2009) has stated, most countries in the world declare themselves to have democratic forms of government and yet this is far from being the truth. Citizen participation in governance is sporadic and largely limited to elections. The distribution of public resources is conducted beyond the reach of citizens. Some groups, for example, indigenous people, people with disabilities or lower levels of education as well as women have difficulty accessing public affairs, wield limited political influence and have little opportunity to defend their needs and interests. In many countries there are se- 
rious problems with young people and the wider public showing a declining interest declining in political participation and engagement in public affairs, both nationally and at the European level (Zápotočná \& Lukšik, 2010). This is accompanied by further problems such as social exclusion, a lack of social cohesion (Nelson \& Kerr, 2006; Schultz et al., 2010; Schmeets \& Couman, 2013), lower levels of trust as well as a public tendency not to engage critically with political elites or express solidarity with those on the fringes of society or in difficulty. Specific examples of this are the lack of interest in/rejection of migrants found in central Europe and low levels of empathy for their problems.

In addition to the low levels of citizenship participation found among young people, there is a tendency for some of them to favour extremist or anti-system movements. In Slovakia this can be seen in young people's support for the political party L'udová strana naše Slovensko (People's Party of Our Slovakia) which openly expresses a hatred of migrants and Roma, and implicitly questions the institutions of democracy. This party was surprisingly successful in the 2016 parliamentary elections (obtaining $8 \%$ of the vote). The post-election analysis indicated that those who voted for the party tended to be first-time voters - the generation of young people born after 1989 that has no experience of communism and whose civic awareness was formed under post-communism. Moreover, this generation is influenced by the new media and social networks, which form an environment that naturally tends to favour conspiracy theories, historical shortcuts and half-truths. Following the elections, a discussion emerged in the media and among experts on whether one of the reasons for this tendency towards extremism among young people could be a lack of education and specifically the poor quality of education in subject areas dealing with citizenship, human rights and so on.

Most often there is an analysis or a critique of civic education that is related to older students in the secondary level (or higher) because it is assumed that it is premature at the primary level. In spite of this shared assumption, some experts emphasize that for development of effective citizenship, a key role may be played by the primary level (Tourney-Purta \& Barber, 2011; Stará, 2004) or even preschool education (Bae, 2009; Moss, 2007). That is why in our study we focus on civic education in the primary level - our effort is to find out how teachers perceive existence of civic education at the primary level in the specific historical context that shaped the Slovak form of education. 


\section{Civil Education - Some Current Trends}

According to Himmelman (2013, p. 16) "in the last ten to fifteen years we have witnessed various attempts to revise and revitalise citizenship education". This is one response to the many social and political challenges of today. Schools have to prepare pupils for life in an integrating Europe and a globalised world, for the growing influence of new information and communication technologies (ICT), potential travel and migration, changes in the nature of work, the strengthening of the rights of indigenous people and minorities, changes in the role of women, the creation of new kinds of communities, and so forth (Keating, 2016; Kerr, 1999).-"European educational policy is no longer ethnocentric but now follows a post-nationalist model that emphasises a common European history and culture as well as civic values, educational skills and a shared future" (Keating, 2009, p. 136). According to Himmelmann "New ways of 'teaching democracy' and 'education of, for and through democracy' are being developed that will go beyond traditional instruction on political institutions" (Himmelmann, 2013, p. 16).

The long-term goal of public education in Western countries is to prepare young people for active participation in the civic and political life of their communities and countries (Flanagan \& Faison, 2001, Lerner, 2004). The effectiveness of a number of models is being debated, with three standing out in particular. The first is moral education, which is an ethics based programme that places citizenship in the context of moral behaviour. The second is an educational programme in which the emphasis is on mediating social science-based knowledge. While the last is informal citizenship education, which stresses the need to acquire direct authentic experience (Zápotočná \& Lukšík, 2010b) via for instance the popular service learning model (for more, see Allen, 2003; Stará, 2004; Lárusdóttir, 2013).

Although these models are the three most frequently mentioned in the literature, citizenship education need not be reduced to precisely determined subject areas but can be provided more generally. It is taught in schools through extracurricular activities (class representatives, pupil councils, pupil parliaments, unions, association, etc.) or by cultivating a particular school culture/atmosphere/ethos. Research on primary school culture has shown that those who tend to participate in civic life have attended schools that focus on developing communicative skills such as expressing and formulating opinions, forming arguments and discussing, understanding differences in opinion and which emphasise cooperation. Schools such as these also tend to emphasise the development of language skills and 
the acquisition of knowledge, a sense of duty, good morals and behaviour (Lukšîk \& Zápotočná, 2010).

In addition, there is civil literacy, in which educating people to be citizens is not based around specific cognitive or conative goals but on the premise that a greater degree of civic participation can be achieved by educating the population; specifically, improving reading, functional and critical literacy. Therefore, citizenship education goals are not tied to a specific sphere of knowledge, or to values or skills, or a particular school subject, but to the cognitive aspects of citizenship activities that involve working with texts and specific textual genres. In his extensive empirical research, Milner (2002) defines civil literacy as the capacity and competency of citizens to make sense of the political world, which is an essential part of being willing and capable of engaging in public discourse, dealing with the authorities and the state and holding them to account.

Another way of cultivating the desired civic attitudes and skills is to develop virtue in the Aristotelean ${ }^{1}$ orthos logos sense. This refers to practical wisdom, making the right judgment, and, according to Aristotle, it is what makes a good citizen. Unlike in moral education the desired virtues are not cultivated under artificial ad hoc conditions, such as in the ethics classroom, but across other subjects such as language, art, music and literature. These virtues are cultivated through the study of myths and the collective 'story telling' that conveys the world of human emotions such as love, faith, hope, the meaning of life, the fate of the individual, society and the world (Palouš, 2008). The rehabilitation of narration in teaching methods assumes that 'we learn something rather than learning about something'. Simply attributing a well-known work of literature to a Russian classicist will not suffice; the key is to understand the context of that particular era and situation by reading about it, as it is conveyed to us in the way people thought and acted, and through human experience that teaches, cultivates and educates.

There has also been discussion of continuum between minimal and maximal citizenship education interpretations (McLaughlin, 1992; Kerr, 1999; Nelson \& Kerr, 2005). The minimal approach is also known as civic education, which is content-led and knowledge-based. The second takes both a formal and informal approach and is not simply about conveying information but about how it is used and about participation both inside and

Two areas of the arts that Aristotle concentrated on in his work, including in relation to their educational potential, are tragedy and music (see Poetics and Politics). 
outside the classroom. The assumption is that countries with liberal, individualistic traditions tend to follow the minimal model and those with communitarian and civic republican traditions are more likely to develop a maximal approach (Nelson \& Kerr, 2005). The question is whether this assumption holds true for eastern European countries with their short liberal individualistic histories and their long communist traditions based on a communitarian ideology but largely individualistic lifestyles. In the contemporary citizenship education model, or education for democratic citizenship, the emphasis is on schools not only educating children for national citizenship but also for global and local and regional citizenship. This type of education includes "political literacy, critical thinking, conflict-free problemsolving, public discussion and communication as well as intercultural communication" (Keating, 2016, p. 41).

In a broader sense citizenship education can also be considered to be the socialisation of citizens, with participants acquiring the norms and behaviours and so forth associated with that society (Rapaport, 2015, p. 17). Engle and Ochoa (1988, in Rapaport, 2015, p. 19), however, add that in addition to socialisation, which is a form of coercion, there must also be a kind of counter-socialisation or learning process that develops independent thinking and social criticism. The citizenship education model found in communist schools, characteristically known as civic education, involved total socialisation and almost no counter-socialisation.

\section{Slovak Curricular Framework}

Citizenship education comes in different types, varying in concept and form, and it is generally set out in curricular documents. Common to all education systems is the emphasis on the importance of citizenship education and the acquisition of social and civic competences. However, the ways in which they choose to implement the subject area at school level differs from one country to another. Citizenship education can be taught as a standalone subject, as a topic integrated within another subject or curriculum area, and/or as a theme to be taught through a cross-curricular approach. These differences can also be found at the various levels of schooling: in 20 education systems, central level curricula treat citizenship education as a compulsory separate subject, sometimes starting at primary level but, more usually, at the lower secondary and/or upper secondary level (Eurydice, 2012). Citizenship is a separate compulsory subject at primary and secondary level in Estonia, Greece, Spain, France, Portugal and Romania, and in France and Portugal it is compulsory from the age of 6 . An overview of 
the time allocated to the subject during compulsory schooling can be found in the relevant European Commission document (Eurydice, 2012).

The Slovak primary school curriculum does not contain a subject that is equivalent to the social studies found in the US tradition; however, there is a subject that is similar in content but a much less substantial form of citizenship education. Both the social studies found in the US and the Slovak equivalent vlastived $a^{2}$ are primarily designed to enable primary school pupils to orientate themselves in time and space. However, given the different historical backgrounds of the countries, the subject is naturally framed quite differently.

Vlastiveda was first taught as a separate subject in 1930-1933. Although the Czechoslovak Republic had been founded earlier, it took 15 years for its various education systems to become harmonised. Slovak teachers were used to the Hungarian system in which vlastiveda was taught as part of first language lessons or reading classes, while the Czechs had been familiar with the Austrian concept of vlastiveda since 1915. The need to introduce more substantial or real-life subjects alongside the more humanities-oriented ones was brought about by scientific advances, new knowledge and the need to establish a conception of the nation. The concept of vlastiveda was first used in 1816 by C. W. Harnisch (Dvořák \& Dvořáková, 2005) who lived in Prussia, where the doctrine of nationalism was developing that would become the driver leading to Europe overtaking the US in establishing this type of school subject.

A brief historical reconstruction will help clarify why Slovak vlastiveda took this form and not that of the social studies found in the US for example. Social studies is a kind of propaedeutic social science found in the content taught at the preschool level, and it is also a separate subject at the primary, secondary and tertiary levels. The difference between Slovak vlastiveda and the social studies taught in schools in the US for instance is not found in the name alone ${ }^{3}$; it is primarily a difference in the content or breadth of the subject (Dvořák \& Dvořáková, 2006), which of course has been influenced by differences in the historical determinants under which the subject was established.

2 Vlastiveda is perhaps best understood through the German equivalent Heimatkunde, where the key concept is Heimat, which roughly means a sense of belonging, and refers to the study of the primordial concept of the nation.

3 The subject is taught in the social studies sense in countries influenced by the US tradition (Canada, Australia, New Zealand). 
Social studies were standardised both as a school subject and in terms of substance across the US from 1905 on. On the basis of the Report of the Committee of Eight for the American Historical Association on history in the elementary schools, US schools began to incorporate history, geography and political science into their curricula from 1916 onwards. "The "subject matter" for this new school subject was to be drawn from the most influential social sciences of the time - history, geography, and civics - and blended together as one school subject for the purpose of helping children understand our American heritage and acquire the skills and sensitivities basic to constructive participation in our nation's democratic society' (Maxim In Mindes, 2005).

As stated above, the different historical determinants meant that the social science taught at primary level in the USA revolves around various social science and humanities disciplines, while in Slovak vlastiveda the emotional and patriotic aspects are emphasised (Kancír \& Madziková, 2003); nonetheless, it is still a propaedeutic form of the history and geography taught later. The continual changes the education programmes have undergone in Slovakia since 2008 have not extended vlastiveda to include other social science knowledge.

In addition to the citizenship education existing in vlastiveda, other elements can also be found in the subjects of ethics and religious education ${ }^{4}$. Ethics contains topics such as active participation in the life of society and the classroom; learning basic social rules and norms; understanding the importance of cooperation; gender sensitivity; environmental protection; an awareness of the law; expressing solidarity with those who are suffering; prosocial behaviour; and attitudes to the disabled, sick and elderly. Religious education ${ }^{5}$ topics that are or may be citizenship-oriented include ethical norms in the ten commandments and examples from biblical events and the lives of saints; the uniqueness of man and differences between man and animals; people's responsibilities to nature; suffering and compassion; helping the needy, distinguishing between private and common property; distinguishing good from evil; sins, guilt and forgiveness; and respect for other churches and religions.

4 In Slovakia ethics and religious education are subject options, and parents or pupils must select one or the other.

5 These are taken from the religious education section of the State Education Programme and relate to Catholicism, the most widespread in religion in Slovakia. 
It is generally the case that citizenship education in Slovakia is taught indirectly and peripherally as part of vlastiveda, ethics and religious education. Vlastiveda also has a regional dimension, and fostering citizenship is narrowly focused on patriotism. Ethics is based on a psychological prosocial model and developing prosocialism, especially within the school. Religious education contains topics that relate primarily to Christian ideology. Thus it would appear that the citizenship education model taught in Slovakia corresponds to the minimal model (Keer, 1999; Nelson \& Kerr, 2005). Since citizenship education is not clearly defined, the work of the teacher becomes more important. It is this that we shall now analyse using the findings of the empirical research we conducted.

\section{Research into Teachers' Perspectives on Citizenship}

Regardless of the preferred conception of citizenship education, the teacher is an essential element in educating the citizen, since the success of the variant adopted lies with the teacher. It is through the teacher that the pupils can gain access to the substance of the more/less active model of citizenship selected and its local, national or global dimension.

Research performed among secondary school teachers in the Netherlands has shown that in citizenship education most teachers focused on adaptive citizenship, i.e. discipline and social commitments, while the individualist approach that emphasises critical thinking and autonomy is less widespread, and only a small section focus on critical democratic citizenship, including critical thinking and autonomy as well as social commitments (Leenders, Veugelers, \& De Kat, 2008). A study by Wood (2012) highlights the fact that what teachers focus on in citizenship education depends on the socio-economic level of the school's community. Teachers from schools in lower socio-economic communities preferred to focus on local citizenship, while teachers from schools in higher socio-economic areas favoured a national and global focus.

Nogueira and Moreira (2012) have outlined the dimensions of a civic education teacher's knowledge. Alongside knowledge of content, curriculum, pedagogical approaches, resources, context and the students' and teachers' understanding of citizenship), they also include citizenship education orientations, which is the central theme of this study. The authors define citizenship education orientation as what the teacher considers to be the purpose, topics and main aims of citizenship education. 
Furthermore, we will refer in more detail to the research that was carried out among primary education teachers in Slovakia. Since there is no separate citizenship subject or a specifically defined citizenship study area at the primary school level in Slovakia, we were interested in what teachers focus on in this area of their teaching and how they informally influence pupils. We focused specifically on one dimension of the civic education teacher's knowledge - citizenship education orientations - defined by Nogueira and Moreira (2012) as the teacher's beliefs about the purpose and main aims of citizenship education. We are interested in teachers' perspectives on citizenship education and whether these correspond to the narrow, minimal model (civic education) that deals with knowledge about the country and system of government or the maximal approach that uses formal and informal approaches and focuses on information, the use of it and also participation. In addition, we asked whether teachers focus only on regional and national citizenship or whether global citizenship is considered as well. If we consider this broader perspective of citizenship education as our basis, civic engagement outside the school environment should also play a role in teachers' perspectives. The culture of the school the teacher works at is clearly important (here we shall only investigate connections relating to the ethnic and social composition of the teacher's classes). Another question that is investigated is the extent to which the teacher's perspective on citizenship relates to the number of pupils in the class that come from socially disadvantaged or ethnic minority backgrounds.

The research was performed using quantative methodology. A questionnaire was created to investigate the focus adopted by primary school teachers in citizenship education and contained a wide range of topics: 1 . The country and region the child lives in (example item: The child is proud of his/her country), 2. The EU (The child has a basic knowledge of the European Union), 3. Cultural, ethnic and religious diversity (The child respects racial, cultural and religious diversity, and rejects racism), 5. Environmental issues (The child knows how to separate waste), 6. Global problems (The child knows about global problems relating to poverty, health and the environment), 7. Legal awareness and protection (The child can defend his or her rights if they are breached), 8. Institutions (The child knows that public affairs are regulated by central and local government), 9. School rules and organisation (The child respects the school rules and the way the school operates), 10. Class rules and organisation (The child knows the rules drawn up in the teacher/pupil contract), 11. Diversity of opinion and discussion (The child understands the opinions and arguments of others), 12. Equal, just and fair treatment (The child can point out when justice and fair treat- 
ment are not meted out), 13. Common good, solidarity (The child fosters the common good of an entity: class, school, community), 14. Solidarity (The child expresses solidarity with those who are socially weaker). In relation to each topic, we also asked about knowledge (what the children should know about that topic) and skills (what the child should know how to do in relation to that topic) because we wanted to capture both the knowledge side of citizenship and active practice.

The questionnaire also contained demographic questions about the respondents' age, length of service, ability to communicate in a foreign language, long periods spent abroad, any active participation in civic associations, political parties and church groups, and about the locality (urban, rural) and size of the school they taught in. It was administered electronically to primary school teachers. Responsibility for issuing instructions and encouraging respondents to compete the questionnaire lay with students from the faculty of education in Trnava as part of their primary school placements. Respondents who participated in the research gave their informed consent. The questionnaire was anonymous.

The research sample consisted of 703 teachers, of whom $95.4 \%$ were women. The respondents were aged between 22 and 79, with a mean age of 40.3. The average length of service was 15.8 years. The teachers were from schools in all the Slovak regions, and the proportion of rural schools was 49.9\%, while $50.1 \%$ were urban.

The data obtained were subjected to a factor analysis using SPSS. The factor analysis was exploratory in character, and the method of extraction used was maximum likelihood. In addition, Table 1 lists the factors of civic orientation of primary education teachers ${ }^{6}$.

Table 1: Factors of citizenship education orientations of primary school teachers

\begin{tabular}{|c|l|l|}
\hline $\begin{array}{l}\text { No. of } \\
\text { factor }\end{array}$ & Name & Explanation of the factor values \\
\hline 1 & $\begin{array}{l}\text { School and class rules } \\
\text { and equivalence }\end{array}$ & $\begin{array}{l}\text { A higher value indicates greater emphasis on } \\
\text { knowing the rules created between pupils and } \\
\text { teacher, knowing the school rules, respecting } \\
\text { them and equal, non-negligent approach to } \\
\text { otherness. }\end{array}$ \\
\hline
\end{tabular}

6 The calculations that preceded the construction of this table are available from the authors. 


\begin{tabular}{|c|l|l|}
\hline 2 & $\begin{array}{l}\text { Knowing how institutions } \\
\text { operate and pride at } \\
\text { being an EU member }\end{array}$ & $\begin{array}{l}\text { A higher value indicates greater emphasis on } \\
\text { knowing how central and local government } \\
\text { work, the differences between them, basic } \\
\text { knowledge and pride at being an EU member }\end{array}$ \\
\hline 3 & $\begin{array}{l}\text { Being familiar with } \\
\text { and fostering diversity, } \\
\text { justice, forming } \\
\text { arguments and and legal } \\
\text { awareness }\end{array}$ & $\begin{array}{l}\text { A higher value indicates greater emphasis } \\
\text { on being familiar with racial, cultural and } \\
\text { religious diversity and diversity of opinions and } \\
\text { on encouraging non-disrespectful behaviour } \\
\text { among children who are different, an emphasis } \\
\text { on recognising fair and just treatment and } \\
\text { an emphasis on disagreeing with others and } \\
\text { support for legal awareness. }\end{array}$ \\
\hline 4 & $\begin{array}{l}\text { Global and environmental } \\
\text { problems }\end{array}$ & $\begin{array}{l}\text { A higher value indicates greater emphasis on } \\
\text { knowing about global problems (poverty, health } \\
\text { and environmental problems) and the problems } \\
\text { associated with a consumer society }\end{array}$ \\
\hline 5 & Regional focus & $\begin{array}{l}\text { A higher value indicates greater emphasis } \\
\text { on knowing the region's special features } \\
\text { and traditions, and encouraging the child to } \\
\text { participate in events held regionally }\end{array}$ \\
\hline
\end{tabular}

As is clear from the descriptions of the factor values in table 2, the emphasis in all the factors, apart from factor 4, is on knowledge of that area and actively working with information, having an active attitude or being active in that area.

In the subsequent analysis we focused on the individual factors and some of the demographic characteristics of the respondents and the schools in which they teach (age, length of pedagogical practice, ability to communicate in a foreign language, long periods spent abroad, active participation in civic associations, political parties and church groups, and urban/rural school locality and size). The correlation analysis of the factor scores and the demographic variables indicates that only some factors correlate with the demographic characteristics. Factor 1: School, class rules and equivalence correlates negatively with active participation in civic associations, foundations and political parties $(\mathrm{R}=-.114$, sign. $=.004)$ and positively with the number of pupils from socially disadvantaged backgrounds $(\mathrm{R}=.108$, sign.=.010). Factor 3: Being familiar with and fostering diversity, justice, forming arguments and legal awareness positively correlates with age, resp. length of pedagogical practice $(\mathrm{R}=.095$ sign. $=.041$ resp. $\mathrm{R}=.085$, sign. $=.039)$, active participation in a church group $(R=.129$, sign. $=.001)$ and participation in civic associations, foundations and political parties $(\mathrm{R}=.086$, sign.=.03). Factor 4: Global and environmental problems correlates negatively with school size $(R=-.119$, sign.=.004). Factor 5: Regional focus correlates positively with age and length 
of pedagogical practice $(\mathrm{R}=.152$, sign. $=.001$ resp. $\mathrm{R}=.113$, sign.=.006). No correlation was found between factor 2 and 3 and demographic characteristics of the respondents as well as between all factor scores and ability to communicate in a foreign language, long periods spent abroad.

\section{Conclusions and Discussion}

The explorative research indicated that teachers provide civic education on the primary level, in spite of the fact that it is not systematically developed on the structural level. They focus on various aspects of citizenship education. None of these aspects was restricted to a narrow patriotic focus as might be expected given the patriotic focus in vlastiveda, the main subject in which citizenship is taught in Slovakia. The factor that comes closest to the perspective adopted in vlastiveda is factor 2, where the emphasis is on knowledge about how the institutions operate; however, this factor was expanded to include pride in EU membership. The existing curricular framework overlaps most with factor 3, where the emphasis in on knowledge about fostering diversity, justice, forming arguments and legal awareness. In a sense this factor is also linked to the approach adopted in ethics, with its psychological prosocial direction, but it goes beyond this as well. Factor 1 , in which the emphasis is on school, class rules and equivalence indicates that pupils are clearly being prepared for life in a democratic society within the culture of the school. Other factors indicated a regional focus that comes close to the content taught in vlastiveda as well as a global focus among teacher that goes beyond the scope of vlastiveda.

The results indicate that all the foci (factors), place equal emphasis on having knowledge of the area, an active attitude and being directly active. This lends support to the notion of an active citizenship or "education through democracy", or the informal model of citizenship education that emphasises the need for pupils to acquire direct authentic experience (Zápotočná \& Lukšík, 2010; Himmelmann, 2001). The rich content of the teachers' perspectives and the fostering of active citizenship suggests that the model closest to the direction adopted by the teachers is the maximal model, also known as civics education, which focuses on formal and informal approaches and information and its use and participation both inside and outside the classroom (Keer, 1999; Nelson \& Kerr, 2005). This tendency to favour the maximal model suggests there has been a loosening of the narrowly patriotic model or nationalist focus in citizenship education; at least in the thinking of teachers who have been working in the Czechoslovak and central European region for decades. 
The results suggest that there is a civic form of socialisation that is realised through having knowledge of and respecting the rules of school institutions and/or knowing how other institutions operate. It would also appear to be the case that to a lesser extent there is also a process of counter-socialisation in schools; the development of independent thinking and criticism (Engle \& Ochoa, 1988) through teachers allowing or encouraging children to form their own opinions, arguments and take part in discussion. In this case the results seem to confirm the idea that teachers are more strongly oriented towards adaptive citizenship rather than critical citizenship (Leenders, Veugelers, \& De Kat, 2008).

To some extent these results correspond with the findings presented in Stará (2005) about Slovakia's neighbour, the Czech Republic, which has a similar historical experience. She asserts that teachers not only emphasise the acquisition of knowledge but also the development of values and critical thinking. However, the problem is that the curriculum does not provide teachers with sufficient space for this kind of teaching, and even if there was the space, the teachers lack the skills required to teach pupils values and about participation or to develop critical thinking. Although Slovakia has historically been influenced by a strong nationalistic tradition (most notably the primordial model), the research would appear to show that teachers, in their role as part of the more educated section of the population, feel the need to carefully deconstruct the patriotic model of education, despite it being only superficially expressed in the curricular documents. The question is whether this 'change' in teachers' thinking has been substantially influenced by the third sector and the wide range of activities it engages in, including various projects aimed at providing schools with education modules (feminist, environmental, human rights NGOs, UNICEF, the Council of Europe) rather than by the national curriculum, which is only slowing beginning to address these issues, and barely at all at the primary level. Since 2011 the national curriculum has been revised three times; however, the commission responsible for vlastiveda has never considered changing the name of the subject or expanding its scope. In fact, there has been a tendency for geographical knowledge, in the form of natural science, to dominate over social science, which, in vlastiveda, is taught mostly through history.

The various different foci the teachers adopt in citizenship education clearly reflect the non-specific and unsystematic nature of citizenship education as laid down in the Slovak State Education Programme for primary schools. In much the same way as, following the change in political regime in 1989, citizenship education became a 'conglomerate of social science', or 
a catch-all for everything that does not fit elsewhere (Mistrik, 1996), citizenship education today appears to be a conglomerate of particular themes; fortunately, these emphasise particular aspects of citizenship. These themes extend beyond the largely national and prosocial focus of the national curriculum in the vlastiveda and ethics topic areas of diversity of opinion and ethnic, religious and cultural diversity.

The rich variety of topics surpasses the recommendation made by Himmelmann (2001) that primary school teachers should be concerned with developing democracy as a form of living, the acquisition of experience, the learning of personal responsibility, and so forth. Our results show that the self-competencies developed at the primary level are the ones pupils can acquire by learning the rules according to which the school and classes operate, by recognising and responding to physical diversity and diversity of opinion. Moreover, the concept of democracy as a form of living is also present, which emphasises the common good, regional identity and national and environmental awareness. Our results suggest that, as in factor 1, teachers also focus on the governance of public affairs, which relates to democracy as a form of governance, and forms part of the education taught at the higher levels of the school system. Generally, the richness of the citizenship education direction adopted by teachers can be attributed, on the one hand, to the lack of coherence in education policy that results in content areas not being clearly defined and, on the other, to the creative approaches teachers are able to adopt because they themselves can select $40 \%$ of the curriculum.

The results of the correlation analysis indicate that the perspectives teachers adopt in citizenship education depend on their extracurricular activities, such as participating in church groups, civic associations and political parties. However, this is a finding that requires further research. The results also indicate that the focus of citizenship education is clearly adapted to the social composition of the class. That research did not cast any doubt on Woods' (2012) finding that the school environment affects what teachers focus on in citizenship education.

The explorative research indicated that that teachers focus on various aspects of citizenship education. None of these aspects was restricted to a narrow patriotic focus as might be expected given the patriotic focus in vlastiveda, the main subject in which citizenship is taught in Slovakia. The eclectic model of informal citizenship education that this analysis reveals also includes the teaching of information and participation and the acquisition of experience. In addition, it is regional, national and global in reach. It 
has a socialising dimension (respecting school and class rules) and an antisocialisation one (forming one's own opinions and disagreeing). The results indicate that the focus adopted by teachers in citizenship education also depends on the number of children in the class from socially disadvantaged backgrounds. These results could be used as a basis for the ongoing reform of primary school education, to ensure that citizenship education is more systematic in terms of focus and areas of knowledge, and that specific educational approaches are developed. Because, under these circumstances the civic education could be viewed as occasional and situation.

\section{References:}

Abdi, H. (2003). Factor rotations in factor analyses. In Encyclopedia of social science. In M. Lewis-Beck, A. Bryman, \& T. Futing (Eds.), Research methods. Thousand Oaks (CA): Sage.

Allen, R. (2003). The democratic aims of service learning. Educational Leadership, 60 (6), 51-54.

Bae, B. (2009). Children's right to participate - Challenges in everyday interactions. European Early Childhood Education Research Journal, 17(3), 391-406.

Dvořák, D., Dvořáková, B. M. (2015). Spoločenskovědní vzdělávání. In V. Spilková (Ed.), Proměny primárního vzdělávání v ČR (pp. 209 - 223). Praha: Portál.

Engle, S.H., \& Ochoa, A.S. (1988). Education for democratic citizenship. New York: Teachers College Press.

Himmelmann, G. (2001). Demokratie-lernen als lebens-, gesellschafts- und herrschaftsform. Ein Lehr- und studienbuch. Schwalbach: Wochenschau Verlag.

Himmelmann, G. (2013). Competences for teaching, learning and living democratic citizenship. In M. Print, \& D. Lange (Eds.), Civic education and competences for engaging citizens in democracies (pp. 3-7). Rotterdam/Boston/Taipei: Sense Publishers.

Keating, A. (2009). Educating Europe's citizens: Moving from national to post-national models of educating for European citizenship. Citizenship Studies, 13(2), 135151.

Keating, A. (2016). Educating tomorrow's citizens: What role can schools play?. Foro de Educación, 14(20), 35-47.

Kancír, J., \& Madziková, A. (2003). Didaktika vlastivedy. Prešov: Univerzum.

Kerr, D. (1999). Citizenship education in the curriculum: An international review. The School Field, 10 (3-4), 5-32.

Lárusdóttir, S. H. (2013). Role výchovy a vzdèlávání v procesu utváření morálního přistupu k vedení. Studia Paedagogica, 18(2-3), 141-56.

Leenders, H., Veugelers, W., \& De Kat, E. (2008). Teachers' views on citizenship education in secondary education in the Netherlands. Cambridge Journal of Education, 38(2), 155-170.

McCowan, T. (2009). Rethinking citizenship education: A curriculum for participatory Democracy. London: Continuum. 
McLaughlin, T., H. (1992). Citizenship diversity and education: A philosophical perspective. Journal of Moral Education, 21(3), 235-246.

Milner, H. (2002). Civic literacy: How informed citizens make democracy work. Hanover: University Press.

Mindes, G. (2005). Social studies in today's early childhood curricula. YC Young Children, p. $12-18$.

Mistrik, E. (1996). Minister aj bezdomovec. Civitas, 2(6), p. 1.

Moss, P. (2007). Bringing politics into the nursery: Early childhood education as a democratic practice. European Early Childhood Education Research Journal, 15(1), 5-20.

Nelson, J., \& D. Kerr. (2006). Active citizenship in INCA countries: Definitions, policies, practices and outcomes: Final Report. England: National foundation for Educational Research.

Nogueira, F., \& Moreira, A. (2012). A framework for civic education teachers' knowledge. Procedia - Social and Behavioral Sciences, 47(2012), 1179 - 1183.

Palouš, R. (2008). Je svět (hodnotově) dvojí nebo jeden? In Paidea, 5(2).

Rapoport, A. (2015). Challenges and opportunities: Resocialization as a framework for global citizenship education In J. Zajda (Ed.), Globalisation, ideology and politics of education reforms, globalisation, comparative education and policy research (pp. 11-23). Springer.

Schmeets, H., \& M. Coumans. (2013). The assessment of social cohesion and social exclusion in the Netherlands. Paper presented at the UNESCO workshop on Measuring and Assessing Inclusive Social Policies. Paris, March 25-26.

Schulz, W., Ainley, J., Fraillon, J., Kerr, D., \& Losito, B. (2010). ICCS 2009 International report: Civic knowledge, attitudes, and engagement among lower-secondary school students in 38 countries. International Association for the Evaluation of Educational Achievement (IEA).

Stará, J. (2004). Výchova k demokratickému občanství v primární škole. Praha: UK. Stará, J. (2005). Výchova k demokratickému občanství. In V. Spilková, et al. (Ed.), Proměny primárního vzděláváni (pp. 225-243). Praha: Portál.

Torney-Purta, J., \& Barber, C. (2011). Fostering young people's support for participatory human rights through their developmental niches. American Journal of Orthpsychiatry, 81 (4), 473-481.

Wood, B. E. (2012). Scales of active citizenship: New Zealand teachers' diverse perceptions and practices. International Journal of Progressive Education, 8(3), 77 - 93. Zápotočná, O., \& Lukšík, I. (2010). Modely občianského vzdelávania a ich podiel na formovaní aktivneho demokratického občianstva. In: J. Plichtová (Ed.), Občianstvo, participácia a deliberácia na Slovensku. Teória a realita (pp. 313 - 332). Bratislava: Veda. 


\section{Authors:}

Zuzana Danišková, Ph.D.

Trnava University

Department of School Pedagogy

Priemyselna 4

91843 Trnava

Slovakia

E-mail: zuzana.daniskova@truni.sk

Ivan Lukšík, prof.

Trnava University

Department of School Pedagogy

Priemyselna 4

91843 Trnava

Slovakia

E-mail: ivan.luksik@truni.sk 